\title{
THE STATE POSITION AS A PREFERENT CREDITOR OF THE TAX DEBT IN BANKRUPTCY
}

\author{
RATIH DAMAYANTI \\ Lecturer of Law Faculty of Universitas Negeri Semarang \\ Gedung K Kampus Sekaran Gunungpati Semarang \\ Email: ratihdamayanti@mail.unnes.ac.id
}

\begin{abstract}
Bankruptcy is a decision issued by the Court that resulted in a general confiscation of all the wealth owned and the wealth that will be owned by the debtor in the future. The State has the preference right to tax debt on the property of the Taxpayer. This means that the position of the state as a preferent creditor who is declared to have prior rights over the property of the Taxpayer to be auctioned in public. The state's preference by taxpayer repayment is in fact not as easy as one might imagine, there are some problems. The purpose of article writing is to know the position of the State as a preferent creditor for the tax debt of the taxpayer declared bankrupt and know the obstacles of the State as a preferent creditor to the repayment of tax debt on taxpayers declared bankrupt. Provisions on the State's prior rights include the principal taxes, administrative sanctions in the form of interest, penalties, increases, and tax collection fees. The weakness in the regulation creates an impediment to the application of the State as a preferential creditor who has the preference right, namely the formulation of the preference right itself that is unclear about the notion of the state's position as the preferent creditor, in addition to the overlapping regulation of the preference right (preferent creditor) The Civil Code, the Law on General Taxation and Bankruptcy Laws and Postponement of Debt Payment Obligations which not only the State as the Preference rights holder's creditors.
\end{abstract}

Keywords : Preferent Creditor, Preference right, Tax Debt

\section{INTRODUCTION}

Bankruptcy is a condition in which the debtor is unable to make payments on debts owed by his creditors. The situation is not able to pay normally due to the difficult financial condition (financial distress) of the debtor business that has 
been declining. ${ }^{1}$ While the bankruptcy is a decision issued by the Court that resulted in general confiscation of all the wealth owned and the wealth that will be owned by the debtor in the future. Bankruptcy proceedings and bribery shall be conducted by the curator under the supervision of a supervisory judge, the two officials appointed directly at the time of the bankruptcy verdict are read out. ${ }^{2}$ Bankruptcy under the provisions of Article 1 number 1 of Code No 37 of 2004 concerning Bankruptcy and Suspension of Debt Payment Obligation, hereinafter abbreviated as UUK-PKPU, is a general confiscation of all the wealth of the Bankrupt Debtor whose management and or its ordering is done by the Curator under the supervision of the Supervisory Judge. ${ }^{3}$ The purpose of bankruptcy is that all creditors get paid according to the balance of the small accounts receivable each in a fair and orderly not scramble. ${ }^{4}$ A debtor holding two or more creditors and not paying off at least one debt that has been matured and collectible shall be declared bankrupt by a court decision, either on his own request or at the request of one or more of his creditors (concursus creditorum). ${ }^{5}$

Due to the legal consequences from The Bankruptcy Decision of The judgment of a commercial court declaration will bring the debtor and creditor into certain situation. The legal consequences of the decree of bankruptcy declaration are regulated in Article 21 of UUK-PKPU covering the entire wealth of the debtor at the time of the declaration of bankruptcy statement is pronounced and everything that is obtained during bankruptcy. The declared bankrupt debtor loses all his / her rights to administer and control the assets which have been inserted into the bankruptcy but the debtor declared bankrupt can still do legal acts concerning him / her because bankruptcy only results in the assets of the debtor bankrupt, not the personal debtors bankrupt. If a bankrupt debtor is married then

1 M. Hadi Shubhan, Hukum Kepailitan: Prinsip, norma, dan Praktik di Peradilan, Kencana, Jakarta, 2009, P. 1.

2 Dedy Tri Hartono, Perlindungan Hukum Kreditor Berdasarkan Code Kepailitan, Jurnal Ilmu Hukum Legal Opinion Edisi I, Volume 4, Of 2016, p.1.

3 Article 1 number 1 Code No 37 of 2004 about Bankruptcy and Suspension of Debt Payment Obligations

4 Abdul R. Saliman, Hukum Bisnis Untuk Perusahaan Teori dan Contoh Kasus, Cet.5, Jakarta: Kencana, 2010, p.133.

5 Jono, Hukum Kepailitan, Jakarta: Sinar Grafika, 2013, p. 3 
the bankruptcy also applies to his wife or married husband on the basis of the unity of property. This provision resulted in the entire property of his wife or husband belonging to the unity of property also exposed to bankruptcy confiscation. But this provision does not apply to the property of the wife or husband and the property which is on a gift or inheritance. ${ }^{6}$

Debtor's assets are mutual guarantee to creditors and proceeds from sale of debtor's property must be distributed to creditors in accordance with the amount of its receivables, except if among the creditors based on the law must take precedence in its distribution, as regulated in Article 1132 Civil Code. ${ }^{7}$ There are 3 kinds of creditors known in Civil Code namely:

(1) The concurrent creditors are the creditors who obtain the settlement based on the amount of the respective receivables. The concurrent creditors have the same position of debt repayment of the debtor's possessions without any precedence.

(2) Preferent creditors are creditors who by law are granted the privilege of obtaining early repayment of receivables compared to other creditors. This privilege is given based on the nature of the receivables that must take precedence.

(3) Separatist creditors are creditor holders of material security rights namely mortgage, pledge, mortgage and fiduciary rights. These separatist creditors are separated and not included in the division of bankrupt debtors' property. This creditor may execute his / her right as if there was no bankruptcy. However, the execution rights of such debt guarantees can not be made by the separatist creditors at any time, the creditor must wait for a period of suspension not later than 90 (ninety) days from the date of the decision on the request for the declaration of bankruptcy.

The State has the preference right to tax debt on the property of the Taxpayer. This means that the position of the state as a preferent creditor who is declared to have prior rights over the property of the Taxpayer to be auctioned in public. The State has the right to obtain a repayment of the debts owned by the

Munir Fuady, Hukum Pailit dalam Teori and Praktek, Jakarta: Citra Aditya, 2014, p. 71.

Kartini Muljadi \& Gunawan Widjaja, 2004, Pedoman Menangani Perkara Kepailitan, PT. Raja Grafindo Persada, Jakarta, p. 107. 
taxpayer, prioritizing the various debts owned against other creditors. Payments to other creditors are settled after the tax debt has been paid.

UUK-PKPU mentions the existence of a preference (preferent), but in practice the right may be void. This can lead to a tendency for taxpayers to avoid payment of tax debt. The UUK-PKPU explains that under the circumstances of a bankrupt company or delaying its debt service obligations, a higher creditor's position should take precedence over the payment. One of the provisions of the offending UU-PKPU is article 41 paragraph (3) that "exempted from the provisions of paragraph (1) shall be the act of the debtor's law which is obligated under the agreement and or by law." The explanation is the obligatory act Act for example, the position of paying taxes. However, UUK-PKPU only focuses on the commercial aspect and does not explicitly mention the taxes but the rights of the former in general. That is, if a company experiencing bankruptcy or postpone the obligation to pay the debt, then the position of the Directorate General of Taxation should take precedence but with the judge's judgment. While the tax law in accordance with the Act expressly provides that the repayment of tax debt has the preference right (preferent) for repayment than other debts, except for repayment provided in Article 1139 and Article 1149 Civil Code. ${ }^{8}$ Regarding such exceptions is logical because it is devoted to the cost of the case and the execution fee which is the first measure to save the debtor's property or the taxpayer. The state's prior rights for tax bills on goods belonging to the Tax Payer are provided for in Article 21 of Code No 16 of 2009 concerning General Provisions And Tax Procedures (KUP). Tax liability is a special rule, therefore the state through the Directorate General of Taxes has a "right of predecessor" to exercise confiscation of taxpayer goods which make his possessions or assets as collateral for his debts, as stipulated in Article 21 of the Act The KUP. Given this debt, the preference right of collecting tax debt is stronger than other debts. That is, if the debtor has more than one debt, then the government as the prior holder of the precedence takes preference. If the guaranteed goods are auctioned then the proceeds will be used

8 Sumyar, Dasar-dasar Hukum Pajak dan Perpajakan, Cet. 1, Yogyakarta, Universitas Atmajaya, 2004, hal 95. 
to pay off the debtor's tax debt to the government, then the debts to other creditors.

Based on the above preliminaries can be formulated problem formulation as follows: (1) How is the position of the State as the preferent creditor of the tax debt of the taxpayer declared bankrupt?; (2) What are the constraints of the State as the preferent creditor to the settlement of tax debt on the taxpayer declared bankrupt?

\section{RESULTS AND DISCUSSION}

\section{State Position As Preferent Creditor on Tax Debt}

The position of tax debt is a special privilege, so that the State is domiciled as a preferent creditor having privileges on the property of the Taxpayer shall be auctioned in public. ${ }^{9}$ Article 1134 Paragraph (2) of the Civil Code also provides for the privilege of having higher rank than other indebted persons due to the laws and regulations. The State as the Preferent creditor causes the state to have a preference right over the goods of the Taxpayer and has a higher position than the separatist lender or the concurrent creditor in the bankruptcy law. ${ }^{10}$

The preference right of the State referred to herein shall be in the case of a Taxpayer or a Taxpayer at the same time in addition to having personal debt (civil), also having a debt to the State (fiscal), in which the property of the Taxpayer or the Taxpayer is insufficient to pay off all debts, then the state has the right to precede the tax bill on the repayment of tax debt by taxpayers declared bankrupt. Payments to other creditors are settled after the tax debt has been paid. Provisions on such preference rights include ${ }^{11}$ :

1. Tax principal

9 Article 19 Paragraph (6) Code PPSP Jo. Article 21 (1) Code KUP Jo. Article 1134 Civil Code Jo. Article 60 Paragraph (2) Bankruptcy Code

10 Ishak, Upaya Hukum Debitor Terhadap Putusan Pailit, Kanun Jurnal Ilmu Hukum No. 65, Th. XVII (April, 2015), pp. 189-215.

11 Legal provision of State Preference Right : Article 21 Code No. 28 Of 2007, Article 21 Paragraph (4) and Paragraph (5) Code No. 16 Of 2000, Article 14 Paragraph (1), Article 18, and Article 19 Code No. 19 Of 2000, Code No. 4 Of 1996, Article 1, Article 41 Paragraph (1) and (3), Article 61, Article 113, Article 114 and Article 115, Code No. 37 of 2004, Article 47 Goverment Provision No. 74 of 2011, Article 1137 Civil Code 
2. Administrative sanctions in the form of interest, penalties, increases, and tax collection fees.

The preference right to a tax bill exceeds all other prior rights, except to: a. the cost of a case which is solely attributable to a penalty for auctioning of a moving good and / or immovable property; b. costs incurred to rescue the goods concerned; c. the cost of the case, which is solely attributed to the auction and the settlement of an inheritance. ${ }^{12}$

In the event that a Taxpayer is declared bankrupt, dissolved or liquidated, the curator, liquidator or person or entity assigned to perform the order is prohibited from distributing the Taxpayer's property in bankruptcy, dissolution or liquidation to shareholders or other creditors before using the property to pay the tax debt .

Taxpayers who have been declared bankrupt through the Court Decision and then the decision which has permanent legal force which has had permanent legal force shall be submitted by the District Court to the Auction Office to be used as the basis for the distribution of auction proceeds. The bankruptcy process is a process of the implementation of the provisions of article 1131 and article 1132 of the Civil Code which aims to divide the debtor's property fairly, intended for the creditor to obtain the preliminary execution (pari passa) from the other, as well as the creditor obtaining greater repayment for other (protata). ${ }^{13}$

State'position as a preferent creditor having prior rights over the property of the Taxpayer and the goods of his / her representative. ${ }^{14}$ The preference rights are automatically lost, if not used by the tax authorities, after a period of two years from the issuance of STP or SKPKB or SKPKBT or SK. And Correction of SK. Objection or Appeal unless prior to the fiscal two year period of issuing a Letter of Force to prevent the expiration of the preference right. The precedence to collect the tax debt by itself disappears, if the tax debt has been fully paid.

12 Code No. 19 Of 1997 jo Code No. 19 Of 2000 on Tax Collection under a warrant, Article 19 Paragraph 6 , on exception of Preference Right

13 Munif Rochmawanto, Upaya Hukum Dalam Perkara Kepailitan, Jurnal Independent Vol 3 No. 2, p. 25

14 Article 21 Paragraph (1) Code No. 6 Of 1983 JO Code No. 9 Of 1994 JO Code No. 16 Of 2000 about KUP 


\section{Weakness of State As Preferent Creditor Against Debt Repayment}

An important stage in the bankruptcy process is insolvency that the debtor is unable to pay, as it is at this stage that the bankrupt property is immediately executed and shared, otherwise peace between the bankrupt debtor and the creditors. In performing the division of bankrupt property, must follow the rules contained in Code No. 37 of 2004 About Bankruptcy And Suspension of Debt Payment Obligation (UUK-PKPU), or spread in various other laws and regulations. The position of the creditor is one of the important factors to be considered, whether it is a concurrent creditor, a separatist creditor, a preferent creditor, or a creditor syndicate. The status of the state, as the creditor, and the state's privileges on the payment of tax debt are not clearly regulated in the UUKPKPU. ${ }^{15}$ Concurrent creditors, separatist creditors, preferent creditors, and creditor syndicates are not given a clear understanding.

There is an overlaping terms "privileged creditors", which is between the Civil Code, UUKUP and UUK-PKPU. ${ }^{16}$ Moreover, the KPKPU Law also uses the terms "right to take precedence" and "pre-existing creditors" which are not translated. The provisions on preferential or special privileges provided for in Article 1134 of the Civil Code, are generalist lex. On the other hand, the Civil Code still provides an opportunity for other lex specialist provisions, namely tax laws and bankruptcy laws, to further regulate. Based on the lex specialis derogat lex generalis principle, tax laws may override the Civil Code. The problem is, when the tax law states about its "virtue" because it contains the precedence of the state, whereas the law must be related to bankruptcy law, which is also a lex specialis, then which law becomes "more specialist"? If viewed from the philosophical aspect, the tax is the income for the public interest, even the interests of the nation and state, so the tax law will be judged "more specialist". However, when viewed from the juridical aspect, the two laws are legislative products that have the same degree.

\footnotetext{
15 Explanation Article 2 Paragraph (1) Code KPKPU.

16 Explanation Article 60 Paragraph (2) KPKPU Code
} 
The provisions regarding "privileged creditors" are spread out in several articles. ${ }^{17}$ From the point of view of the law in the field of taxation that is in the Code No 28 of 2007 About Third Amendment to Code No. 6 of 1983 on General Provisions and Procedures of Taxation (hereinafter referred to as the KUP Law) states "the status of the state as creditor preferent "and" having the right of predecessor ", among them is stipulated in Article $21^{18}$ and Elucidation of Article 21. ${ }^{19}$ Similarly to the Code No. 19 of 2000 on the Amendment to Code No 19 of 1997 on the Collection of Taxes by Forced Mail (here in after referred to as the PPSP Code), "the position of the state as the preferent creditor" and "having the right of precedence" contained in Article 19 Paragraph (5), ${ }^{20}$ Article 19 Paragraph (6), ${ }^{21}$ Elucidation of Article 19 Paragraph (6), ${ }^{22}$ and Elucidation of Article 19

17 KPKPU Code: Article 118 Paragraph (2), Article 124 Paragraph (2), Article 138, Article 149 Paragraph (1), Article 162, Article 189 Paragraph (5), Article 198 Paragraph (3), Article 199, Article 200 Paragraph (2), Article 212, Article 213, Explanation Article 2 Paragraph (1), Explanation Article 222 Paragraph (2), Explanation Article 228 Paragraph (4).

18 Article 21 and Explanation Article 21 KUP Code regulate : (1) The State has a prior right to the tax debt on the property of the Taxpayer. (2) Provisions on the preference rights as referred to in Paragraph (1) cover the principal taxes, administrative sanctions in the form of interest, penalties, increases, and tax collection fees. (3) The predecessor right to tax debt exceeds all other prior rights, except to: a. the cost of a case which is only caused by a penalty for auctioning a moving good and a fixed item; b. costs incurred to rescue the goods concerned; and or c. the cost of the case, which is only caused by the auction and the settlement of an inheritance. (3a) In the event that a Taxpayer is declared bankrupt, dissolved or liquidated, the curator, liquidator or person or baand assigned to perform the order is prohibited from distributing the Taxpayer's property in bankruptcy, dissolution or liquidation to the shareholders or other creditor before using the property for pay the tax debt of the Taxpayer. (4) Initial rights disappear after 5 (five) since the date of issuance of Tax Collection Letters, Underpayment Tax Assessment Letters, Additional Paid Tax Assessment Letters of Decision, Decision Letter, Appeal Decision, or Review Judgment causing the amount of tax to be paid increases. (5) The calculation of the timeframe of the preference right shall be stipulated as follows: a. in the case of a Forced Warrant to pay to be formally notified, the time period of 5 (five) of as referred to in Paragraph (4) shall be calculated from the notice of the Letter of Force; or b. in the case of a delayed payment or payment installment agreement then the time period of 5 (five) of which shall be counted since the deadline of delay is granted

19 Explanation Article 21 Paragraph (1) KUP Code regulate "This paragraph establishes the position of the state as the preferent creditor who is stated to have prior rights over the goods of the Taxpayer to be auctioned in public. Payments to other creditors are settled after the tax debt has been paid."

20 Article 19 Paragraph (5) CODE PPSP regulate "The District Court or other authorized institution shall determine the distribution of the proceeds of the sale of goods in accordance with the provisions of the State's prior right to the tax bill."

21 Article 19 Paragraph (6) CODE PPSP regulate "The preference rights to tax bills exceed any other prior rights, except to: a. the cost of a case which is solely attributable to a penalty for auctioning of a moving good and a fixed item; b. costs incurred to rescue the goods concerned; 
Paragraph (7). ${ }^{23}$ Although the "preference right" in terms of tax debt has been described, but again the term "preferent creditor" is not given a clear understanding. The revision of the 2009 KUP Code also fails to clarify what constitutes "the state's position as a preferent creditor" and "has a prior right" and the problem between tax law (as part of public law) and civil or private law.

Weaknesses in regulation create barriers to the application of the State as preferential creditors with prior rights. Some of the problems are the first, the term "the status of the state as a creditor" in the tax law (UU KUP and UU PPSP) is certainly not the same as what is meant by "creditor" as regulated in civil law namely the party giving the debt or credit to Taxpayer. Secondly, if the term "preferred" in the two tax laws above is the same as the "privilege" in Article 1134 of the Civil Code, precisely the "preference right" can not be nominated. The Civil Code regulates certain security holder (ie mortgage and mortgage) for debt repayment, still higher than the privilege, since the tax office does not hold any guarantee from the Taxpayer. ${ }^{24}$ The existence of a creditor who holds a guarantee on the debtor's property also becomes a separate problem. Preferential creditor group, according to Article 1149 of the Civil Code also includes workers and employees of the company on the salary of employees whose rights should be paid immediately.

The KPKPU Law, which does not clearly define the notion of various creditors, certainly makes it difficult to determine the order of parties entitled to the division of bankrupt property. Moreover the term "preferent creditor" to

c. the cost of a case which is solely attributable to the auction and the settlement of an inheritance"

22 Explanation Article 19 Paragraph (6) PPSP Code regulate : "This Paragraph establishes the position of the State as a preferent creditor who is deemed to have a prior right over the goods of the Taxpayer to be sold except for the cost of a case which is solely attributable to a penalty for auctioning of a moving good and a fixed item, the cost incurred to save the intended goods, or the cost of a case which is solely attributable to the auction and the settlement of an inheritance. The proceeds of sale of goods belonging to the Taxpayer in advance to pay the above costs and the rest is used to pay off the tax debt."

23 Explanation Article 19 Paragraph (7) PPSP Code regulate "As a continuation of the determination of the District Court to determine the distribution of proceeds from the sale of confiscated goods with due observance of the preference right to the tax refund, if the said ruling then has a permanent legal force, the District Court shall immediately send its decision to the Auction Office for use as a basis for the distribution of auction proceeds."

24 Y. Sri Pudyatmoko, Pengantar Hukum Pajak, Yogyakarta : Andi Offset, 2008, p.20. 
describe the state's position. ${ }^{25}$ On the contrary, based on the theory of judgment, the judge is subject only to law and justice, no one (including the government) can influence or direct the judgment to be imposed, and there shall be no consequence to the judge's personal in performing his judicial duties and functions. ${ }^{26}$ The reality of the vague norm on the provisions concerning the position of the KPP in the divorce of bankrupt property by the curator, and the state's prior right to tax payment on the Commercial Court ruling should be examined, as it affects a lot of state revenue sources and also aims to other creditors, curators, and KPP get justice and legal certainty from the division of bankrupt property.

The weakness of the application of the State's prior rights is due to the formulation of the preference right itself which is unclear about the notion of the state's position as the preferent creditor. Tunggul Ansari S.N, declares the legislator should pay attention to the following matters so that the tax law will always provide legal certainty for the Taxpayer, namely: 1 . The law must be clear, decisive, does not contain double meaning; 2. Definitions must be clear and resolute not to be smuggled by law; 3 . Give an authentic and clear interpretation of Article 1, do not give an interpretation of the explanation because it can still be interpreted again; 4. The limitative description takes precedence over the "enunsiatif". Verbs such as, among other things, should be avoided; 5. The existence of a legal guarantee in the form of protection of the Taxpayer; 6 . There is a definite understanding of the tax object; 7 . There is certainty about the subject of the tax; 8 . There is certainty about the amount of tax to be paid. When tariffs are made by groups, it must be certain; 9 . There is certainty about how and when to pay taxes. ${ }^{27}$

\section{CONCLUSION}

1). The State as the preferent creditor has the preference right to tax debt on the property of the Taxpayer. The provisions on the preference rights include the

\footnotetext{
25 Tunggul Ansari S.N., Pengantar Hukum Pajak, Malang : Bayumedia, 2006, p. 36.

26 Gerhard Robbes, dalam Ahmad Rifai, Penemuan Hukum oleh Hakim Dalam Perspektif Hukum Progresif, Jakarta : Sinar Grafika, 2014, p. 102.

27 Tunggul Ansari S.N, Pengantar Hukum Pajak, (Malang : Bayumedia, 2006), p. 29
} 
principal taxes, administrative sanctions in the form of interest, penalties, increases, and tax collection fees. The preference right to tax debt exceeds all other predecessor rights, except to: a. the cost of a case which is only caused by a penalty for auctioning of a moving good and / or immovable property; $b$. costs incurred to rescue the goods concerned; and or c. the cost of the case, which is only caused by the auction and the settlement of an inheritance.

2). The weakness in the regulation creates an impediment to the application of the State as a preferential creditor who has the preference right, namely the formulation of the preference right itself that is unclear about the notion of the state's position as the preferent creditor, in addition to the overlapping regulation of the preference right (preferent creditor) The Civil Code, the Law on General Taxation and Bankruptcy Laws and Postponement of Debt Payment Obligations which not only the State as the preference rights holder's creditors.

\section{RECOMENDATION}

There is a need for revamping of regulations related to preferent creditors who have a prior right in bankruptcy. In this regard, it is necessary to consider the equality of formulation and perception of the preference right in the regulations on taxation and bankruptcy, besides that the regulation must provide a clear explanation, as complete as possible, if necessary accompanied by an example. It should be remembered that in law science there are many methods of interpretation of the law, so it is feared to emerge also diverse diverse interpretation results. In the end, the results of such interpretations impair the state's precedent over the payment of the tax debt itself, which is not really applicable when faced with other debts in the bankruptcy procedure.

\section{BIBLIOGRAPHY}

\section{Book Literature:}


Fuady, Munir, Hukum Pailit dalam Teori dan Praktek, Jakarta: Citra Aditya, 2014.

Jono, Hukum Kepailitan, Jakarta: Sinar Grafika, 2013.

Muljadi, Kartini \& Gunawan Widjaja, 2004, Pedoman Menangani Perkara Kepailitan, PT. Raja Grafindo Persada, Jakarta.

Pudyatmoko, Y. Sri, Pengantar Hukum Pajak, Yogyakarta : Andi Offset, 2008.

Ansari, Tunggul S.N., Pengantar Hukum Pajak, Malang : Bayumedia, 2006.

Rifai, Ahmad, Penemuan Hukum oleh Hakim Dalam Perspektif Hukum Progresif, (Jakarta : Sinar Grafika, 2014).

Saliman, Abdul R. Hukum Bisnis Untuk Perusahaan Teori dan Contoh Kasus, Cet.5, Jakarta: Kencana, 2010.

Shubhan, M. Hadi, Hukum Kepailitan: Prinsip, norma, dan Praktik di Peradilan, Jakarta: Kencana, 2009.

Sumyar, Dasar-dasar Hukum Pajak dan Perpajakan, Cet. 1, Yogyakarta, Universitas Atmajaya, 2004

\section{Journal:}

Hartono, Dedy Tri, Perlindungan Hukum Kreditor Berdasarkan Undang-Undang Kepailitan, Jurnal Ilmu Hukum Legal Opinion Edisi I, Volume 4, Tahun 2016.

Ishak, Upaya Hukum Debitor Terhadap Putusan Pailit, Kanun Jurnal Ilmu Hukum No. 65, Th. XVII (April, 2015), pp. 189-215.

Munif Rochmawanto, Upaya Hukum Dalam Perkara Kepailitan, Jurnal Independent Vol 3 Nomor 2, hlm. 25.

\section{Provisions:}

Kitab Undang-Undang Hukum Perdata.

Undang-Undang Republik Indonesia Nomor 19 Tahun 2000 Tentang Perubahan Atas Undang-Undang Republik Indonesia Nomor 19 Tahun 1997 tentang Penagihan Pajak Dengan Surat Paksa. 
Undang-Undang Republik Indonesia Nomor 37 Tahun 2004 tentang Kepailitan Dan Penundaan Kewajiban Pembayaran Utang.

Undang-Undang Republik Indonesia Nomor 16 Tahun 2009 tentang Penetapan Peraturan Pemerintah Pengganti Undang-Undang Nomor 5 Tahun 2008 tentang Perubahan Keempat Atas Undang-Undang Nomor 6 Tahun 1983 tentang Ketentuan Umum Dan Tata Cara Perpajakan. 